Nova Southeastern University

Florida

NSUWorks

$1-1-2018$

\title{
Control the Casinos and Stop the Dogs: Florida's 2018 Proposed Constitutional Amendments
}

Robert Jarvis

jarvisb@nova.edu

Follow this and additional works at: https://nsuworks.nova.edu/law_facarticles

Part of the Constitutional Law Commons, and the Gaming Law Commons

\section{NSUWorks Citation}

Robert Jarvis, Control the Casinos and Stop the Dogs: Florida's 2018 Proposed Constitutional Amendments, 22 Gaming Law Review 393 (2018),

Available at: https://nsuworks.nova.edu/law_facarticles/387

This Article is brought to you for free and open access by the Shepard Broad College of Law at NSUWorks. It has been accepted for inclusion in Faculty Scholarship by an authorized administrator of NSUWorks. For more information, please contact nsuworks@nova.edu. 
Nova Southeastern University

From the SelectedWorks of Robert M. Jarvis

2018

Control the Casinos and Stop the Dogs: Florida's 2018 Proposed Constitutional Amendments

Robert M. Jarvis

NOVA SOUTHEASTERN UNIVERSITY

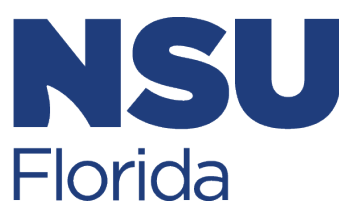

Available at: https://works.bepress.com/

robert_jarvis/25/ 
CONTROL THE

CASINOS AND STOP

THE DOGS:

FLORIDA'S 2018

PROPOSED

CONSTITUTIONAL

AMENDMENTS

\section{ROBERT M. JARVIS}

Robert M. Jarvis is a professor of law at Nova Southeastern University (NSU) and a member of the Editorial Board of Gaming Law Review. The information contained herein is current through July 1, 2018. He thanks his NSU colleague Phyllis Coleman.

\section{INTRODUCTION}

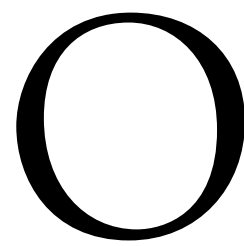

n Tuesday, November 6, 2018, Floridians will head to the polls to cast their votes for numerous offices. ${ }^{1}$ While in the ballot booth, they also will be confronted with 13 amendments to the state constitution. ${ }^{2}$ Two of them-Amendment 3 (casinos) and Amendment 13 (dog racing) - concern gambling. If either or both pass, Florida's betting landscape will be radically altered. Accordingly, this brief article provides a description of these proposals.

\section{FLORIDA'S CONSTITUTIONAL FRAMEWORK}

Florida's current constitution - its sixth overallwas adopted in $1968 .{ }^{3}$ Today, it contains four provisions dealing with gambling:

1. Article $X, \S 7$ bans all lotteries. ${ }^{4}$ In doing so, it also creates an exception for pari-mutuel betting on dog races, horse races, and jaialai matches. ${ }^{5}$

2. Article $X, \S 15$ partially repeals the ban on lotteries. Specifically, it permits the state to run a lottery so long as the "[n]et proceeds [are] deposited [in] a state trust fund, to be designated The State Education Lotteries Trust Fund, to be appropriated by the Legislature." 6

3. Article $X, \S 23$ allows the pari-mutuel facilities in two South Florida countiesBroward and Miami-Dade, respectively,
Keywords: casinos, constitutional law, dog racing, Florida, pari-mutuels

DOI: $10.1089 / \mathrm{glr} 2.2018 .2279$ C 2018 Mary Ann Liebert, Inc.

${ }^{1}$ See Offices Up for Election and Retention in 2018, Florida Div. of Elections, http:// dos.myflorida.com/elections/candidates-committees/offices-up-for-election/. These positions include one U.S. senator, 27 U.S. representatives, Florida's governor and lieutenant governor, the entire state cabinet, 20 state senators, 120 state representatives, and three state Supreme Court justices. Id.

${ }^{2}$ See http://dos.elections.myflorida.com/initiatives/ (under "2018 Made Ballot") Three of these amendments have been proposed by the Florida Legislature (all dealing with taxes); two by citizens (one focused on gambling and the other on the voting rights of ex-felons); and eight by the Constitution Revision Commission (covering such diverse subjects as the criminal justice system, education reform, electronic cigarettes, gambling, government ethics, and oil drilling). See Gray Rohrer, Packed Ballot May Result in Long Lines on Election Day, S. FLA. SuNSentinel, Apr. 23, 2018, at 1B.

${ }^{3}$ For the constitution's text, see http://www.leg.state.fl.us/statutes/index.cfm? submenu=3\#A7S07. For commentary, see Talbot D'Alemberte, The Florida State Constitution (2d ed. 2016).

${ }^{4}$ This provision first appeared in Florida's fourth constitution (1868) as Article IV, $\S$ 20. See http://fall.fsulawrc.com/crc/conhist/1868con.html ("Lotteries are hereby prohibited in this State."). It was retained in the fifth constitution (1885) as Article III, § 23. See http://fall.fsulawrc.com/crc/conhist/1885con.html ("Lotteries are hereby prohibited in this State."). For a further discussion, see Greater Loretta Improvement Ass'n v. State ex rel. Boone, 234 So. 2d 665 (Fla. 1970) (tracing the prohibition's history)
${ }^{5}$ In full, Article X, $\S 7$ reads: "Lotteries, other than the types of pari-mutuel pools authorized by law as of the effective date of this constitution, are hereby prohibited in this state." Florida legalized pari-mutuel betting on dog and horse races in 1931 to raise revenue during the Great Depression. See ch. 14832, 1931 Fla. Laws 679. Jai-alai was added in 1935 for the same reason. See ch. 17074, 1935 Fla. Laws 684

${ }^{6}$ In 1982, a proposal authorizing a state lottery failed to make the ballot. Had it passed, the "[n]et profits [would have been] appropriated to the several counties for public safety purposes, for educational purposes, and for senior citizen assistance purposes." See http://dos.elections.myflorida.com/initiatives/fulltext/pdf/14-19. pdf.

In 1986, Amendment 5, entitled "State Operated Lotteries," made the ballot After surviving a legal challenge regarding its unusual wording, see Carroll v. Firestone, 497 So. 2d 1204, 1207 (Fla. 1986) (finding no violation in the fact that while touted as a way to help schools, the proposal "leave[s] the ultimate disposition of the proceeds received from lotteries, if established, to the discretion of the legislature"), it passed by a vote of $2,039,437$ to $1,168,858$. See $h t t p: / / d o s$.elections myflorida.com/initiatives/initdetail.asp?account $=14 \&$ seqnum $=34$.

The Florida Lottery began operating in 1988; by 2017, it had raised $\$ 32$ billion for the state and annual ticket sales had reached \$6 billion. See Florida LotTERY, Annual Report: Fiscal Year 2016-17, at 2 (2017), available at http://www flalottery.com/exptkt/annualreport17.pdf. Compare Joni James, For the Lottery, A Whole New Look, St. Petersburg Times, Jan. 29, 2005, at 1B (reporting that in 2004 , annual ticket sales were $\$ 3$ billion). As critics predicted, however, see Carroll, 497 So. $2 \mathrm{~d}$ at 1206-08, more often than not, the lottery's proceeds have been used to fund, rather than supplement, the state's education budget. See Advisory Op. to the Att'y Gen. re Requirement for Adequate Pub. Educ. Funding, 703 So. 2d 446, 448 (Fla. 1997) (striking from the ballot a proposed constitutional amendment that would have required the state to spend at least $40 \%$ of its general revenues on education, as it did in "1986-87 before state lotteries began"). 
home to the cities of Fort Lauderdale and Miami- to have slot machines. ${ }^{7}$

4. Lastly, Article VII, $\S 7$ lets the state tax parimutuel betting. The state can share such revenue with the counties (either in whole or in part), but if it does so, all 67 counties must receive the same amount. ${ }^{8}$

Apart from these restrictions, the Florida Legislature is free to do as it pleases when it comes to gambling. The one caveat, of course, is that wagering that is regulated by Congress - such as Indian, ${ }^{9}$ Internet, ${ }^{10}$ and shipboard ${ }^{11}$ betting - largely is outside the state's jurisdiction. ${ }^{12}$

Pursuant to the foregoing, Florida's lawmakers have enacted a detailed gambling code, which now is codified as Chapter 849 of the Florida Statutes. ${ }^{13}$ Its heart is $\S 849.08$ : "Whoever plays or en- gages in any game at cards, keno, roulette, faro or other game of chance, at any place, by any device whatever, for money or other thing of value, shall be guilty of a misdemeanor of the second degree[.]"14

The remainder of the code can be divided into two parts. While most of it implements the ban on gambling created by $\S 849.08$, in a few instances it carves out an exception. Thus, for example, $\S 849.07$ makes it a misdemeanor to bet on billiards, but $\S 849.085$ exempts low stakes (defined as less than $\$ 10$ a hand) card games. $^{15}$

\section{PROPOSED AMENDMENT 3}

Over the years, various citizen groups have attempted to add a casino provision to the Florida Constitution. ${ }^{16}$ None have succeeded.
${ }^{7}$ From the time of their creation (c. 1887) to 1935 , slot machines were illegal in Florida. In 1935, however, as the Great Depression continued to lay waste to the state's economy, Florida legalized them. See ch. 17257, 1935 Fla. Laws 1085. Although the statute was upheld twice by the Florida Supreme Court, see Hardison v. Coleman, 164 So. 520 (Fla. 1935), and Lee v. City of Miami, 163 So. 486 (Fla 1935), it was repealed in 1937. See ch. 18143, 1937 Fla. Laws 909. See furthe Eccles v. Stone, 183 So. 628, 631 (Fla. 1938) (laying out the history of the 1935 and 1937 acts).

In 2002, a proposal to allow slot machines in pari-mutuel facilities located in counties permitting them was struck from the ballot by the Florida Supreme Court. See Advisory Op. to the Att'y Gen. re Authorization for Cnty. Voters to Approve or Disapprove Slot Machines Within Existing Pari-Mutuel Facilities, 813 So. 2d 98 102 (Fla. 2002) ("The initiative considered here purports to create a mechanism for authorizing and taxing slot machines for a particular purpose in the same proposal which would effectively amend article XI, section 7 , to remove this new state tax from the ambit of that provision. Because it thus fails to comport with the constitution's single subject limitation, it is disapproved for inclusion on the ballot."). Had it passed, the proposal would have required lawmakers to use the money received from slot machines to "enhance senior citizen services, classroom construction, education programs, and teachers' salaries and benefits." $I d$. at 99 .

Two years later, Amendment 4, limited to Broward and Miami-Dade counties and requiring all monies to "supplement public education funding statewide," passed Supreme Court review. See Advisory Op. to the Att'y Gen. re Authorizes Miami-Dade and Broward Cnty. Voters to Approve Slot Machines in Parimutuel Facilities, 880 So. 2d 522, 525 (Fla. 2004) ("[W]e hold that the tax allocation provision in the proposed amendment before this Court does not violate the singlesubject requirement."). It then was approved by voters by the narrowest of margins: $3,631,261(50.83 \%)$ to $3,512,181(49.17 \%)$. See November 2, 2004 General Election-Official Results-Constitutional Amendment No. 4, Florida Dep'T or StATE-Div. of Elections, https://results.elections.myflorida.com/?ElectionDate= 11/2/2004\&DATAMODE=. Subsequently, both counties (as required) held loca referendums to authorize the implementation of Amendment 4. While Broward's passed on the first try, Miami-Dade needed two attempts. See Robert M. Jarvis, 2007-2008 Survey of Florida Gambling Law, 33 Nova L. Rev. 231, 235-36 (2008).

${ }^{8}$ In 1957, the Florida Legislature sought to completely overhaul the constitution, but the Florida Supreme Court blocked its efforts on technical grounds. See RiveraCruz v. Gray, 104 So. 2d 501 (Fla. 1958). Among the proposed changes was a new Article VIII, § 8: "The legislature shall have the power to allocate and distribute to the counties, in equal amounts and at such times as it shall determine, any portion or all of the proceeds of state excise taxes on the operation of pari-mutuel pools." See Committee Substitute for House Joint Resolution No. 14-X, http://fall.fsulawrc. $\mathrm{com} / \mathrm{crc} / \mathrm{conhist} / 1958 \mathrm{amen} . \mathrm{html}$. This language is almost identical to current $\mathrm{Ar}$ ticle VII, \& 7, which reads: "Taxes upon the operation of pari-mutuel pools may be preempted to the state or allocated in whole or in part to the counties. When al- located to the counties, the distribution shall be in equal amounts to the several counties."

${ }^{9}$ See Indian Gaming Regulatory Act of 1988, 25 U.S.C. $\S \S 2701-2721$ (2012). After fiercely resisting such gambling for years, Florida in 2010 finally relented and signed a gambling compact with the Seminole Indians. See Matthew L.M. Fletcher, The Seminole Tribe and the Origins of Indian Gaming, 9 FIU L. REv. 255 (2014). For later developments, see Seminole Tribe of Fla. v. Florida, 219 F. Supp. 3d 1177 (N.D. Fla. 2016)

${ }^{10}$ See Unlawful Internet Gambling Enforcement Act of 2006, 31 U.S.C. $\$ \S 5361-$ 5367 (2012). Due to the statute's complexities, Florida has moved slowly with respect to such gambling. See, e.g., Daniel L. Wallach and Marc W. Dunbar, Florida's Uncertain Legal Landscape for Fantasy Sports: A Closer Look, 19 Gaming L. Rev. 644 (2015); Lawrence G. Walters, Florida's Internet Cafés: The Future of Gaming or a Vanishing Loophole?, 15 GAMING L. REv. 465 (2011).

${ }^{11}$ See Gambling Ship Act of 1948, 18 U.S.C. $\S \S 1081-1084$ (2012); Johnson Act Amendments of 1992, 15 U.S.C. $\$ 1175$ (2012). Although Florida invented the modern casino boat industry, and once had the nation's largest gambling fleet, today it has just three casino boats. See Robert M. Jarvis, Florida's "Cruises-to-Nowhere" Industry: Current Status and Future Prospects, 21 Gaming L. Rev. 18 (2017) (explaining that the ships could not compete with the Seminoles' casinos).

${ }^{12}$ Because of the U.S. Supreme Court's recent decision in Murphy v. NCAA, $138 \mathrm{~S}$. Ct. 1461 (2018), sports betting once again is under state control. (In Murphy, the Court found that the Professional and Amateur Sports Protection Act of 1992, 28 U. S.C. $\S \S 3701-3704$ (2012), violated the Tenth Amendment)

${ }^{13}$ Chapter 849 is supplemented by Chapters 550 (which regulates pari-mutuel wagering) and 551 (slot machines)

${ }^{14}$ FLA. STAT. $\S 849.08$ (2017)

${ }^{15}$ For a further look at how Chapter 849 functions, see, e.g., David G. Shields, Slot Machines in Florida? Wait a Minute, 87 FLA. B.J. 8 (Sept./Oct. 2013); Miriam S. Wilkinson and Eric H. Miller, Florida Game Promotions Statute: A Novel Application of an Exception to Florida's Prohibition on Gambling, 11 Gaming L. Rev. 98 (2007); Marc J. Randazza, Condo Casino! Gambling Law and the Florida Community Association, 79 FLA. B.J. 8 (Oct. 2005).

${ }^{16}$ Article XI, $\S 3$ of the Florida Constitution permits citizens to place constitutional amendments on the ballot if they meet certain requirements, including collecting a sufficient number of signatures (currently set at 766,200). See Florida Dep't of State-Div. of Elections, 2018 Initiative Petition Handbook (2017), available at http://dos.myflorida.com/media/697659/initiative-petition-handbook-2018-electioncycle-eng.pdf. Unlike some states, Florida does not permit citizens to place statutory proposals on the ballot. 
In 1978, Amendment 9, entitled "Casino Gambling," lost by a $3-1$ margin $(1,720,275$ to 687,460$) .{ }^{17} \mathrm{Had}$ it passed, it would have authorized casinos along the beaches in Broward and Dade ${ }^{18}$ counties. ${ }^{19}$ The taxes generated by these enterprises would have gone "for the support and maintenance of the free public schools and local law enforcement.",20

In 1982, a proposal entitled "Local Government" failed to make the ballot. ${ }^{21} \mathrm{Had}$ it been adopted, it would have ensured, in the event that Florida ever did legalize casinos, that each county would be allowed to decide for itself whether it wanted them. ${ }^{22}$

In 1984, a proposal entitled "Additional Forms of Gambling Authorized" failed to make the ballot. ${ }^{23}$ It would have permitted every hotel in Dade County that had at least 350 rooms to have a casino. ${ }^{24}$ Other counties would have had the option of extending the same privilege to their hotels, so long as they also had at least 350 rooms. ${ }^{25}$

In 1986, Amendment 2, entitled "Casino Gambling Authorized Subject to County Option," lost by more than a million votes $(2,237,555$ to $1,036,250) .{ }^{26} \mathrm{Had}$ it passed, it would have allowed any hotel that had at least 500 rooms to have a casino if its county approved. $^{27}$

In 1994, Amendment 8, entitled "Limited Casinos," lost by nearly a million votes $(2,555,492$ to $1,566,451) .{ }^{28}$ Had it passed, it would have allowed Duval (Jacksonville), Escambia (Pensacola), Hillsborough (Tampa), Lee (Fort Myers), Orange (Orlando), Palm Beach (Palm Beach), and Pinellas (St.

\footnotetext{
${ }^{17} \mathrm{See}$ http://dos.elections.myflorida.com/initiatives/initdetail.asp?account=14\&seq num $=1$.

${ }^{18}$ From 1836 to 1997 , Miami-Dade County was known as Dade County. The name was changed in 1997 to promote growth. See Mireya Navarronov, Miami Lends Good Name, and Bad, to Needy Region, N.Y. TIMES, Nov. 29, 1997, at A1 ("When residents of Dade County voted this month to rename their county Miami-Dade, they acquiesced to arguments by public officials that they should bank on the 'magic' of the name Miami to attract more business.").

${ }^{19} \mathrm{See}$ http://dos.elections.myflorida.com/initiatives/fulltext/pdf/14-1.pdf.

${ }^{20} I d$. For a further look at this proposal, see Floridians Against Casino Takeover v. Let's Help Florida, 363 So. 2d 337 (Fla. 1978).

${ }^{21} \mathrm{See} \mathrm{http} / /$ dos.elections.myflorida.com/initiatives/initdetail.asp?account=14\&seq num=18.

${ }^{22} \mathrm{See}$ http://dos.elections.myflorida.com/initiatives/fulltext/pdf/14-18.pdf.

${ }^{23} \mathrm{See}$ http://dos.elections.myflorida.com/initiatives/initdetail.asp?account=14\&seq num $=32$.

${ }^{24}$ See http://dos.elections.myflorida.com/initiatives/fulltext/pdf/14-32.pdf.

${ }^{25} I d$.
}

Petersburg) counties to each have one casino; Broward County to have two casinos; Dade County to have three casinos (with two in Miami Beach and the third elsewhere in the county); every pari-mutuel facility to have a casino (limited to 75,000 feet); and five additional counties (to be selected by the legislature) to each have one riverboat with a casino no larger than 40,000 feet. $^{29}$

At the same time as Amendment 8, two other proposals failed to make the ballot. The first, entitled "Casino Authorization, Taxation and Regulation," was much more liberal. ${ }^{30}$ It would have let the voters of any county or Tourist Development Council district authorize casinos on commercial vessels and riverboats, within existing pari-mutuel facilities, and at hotels. $^{31}$

The second, entitled "Limited Gaming and Casinos," was more cautious. ${ }^{32}$ It would have let counties authorize gambling on "State Regulated, privately owned Riverboats and on U.S. registered commercial vessels," allowed casinos of up to 75,000 feet in all existing pari-mutuel facilities, and created three "gaming and casino districts," with one straddling northern Dade and southern Broward counties and the other two at locations designated by the legislature. $^{33}$

In 1996, a proposal entitled "Authorization for and Regulation of Statewide System of Limited-Access Riverboat Gambling Casinos" failed to make the ballot. ${ }^{34}$ Had it succeeded, it would have allowed the legislature to license up to 21 riverboats, with no

\footnotetext{
${ }^{26}$ See http://dos.elections.myflorida.com/initiatives/initdetail.asp?account=14\&seq num=33.

${ }^{27} \mathrm{See}$ http://dos.elections.myflorida.com/initiatives/fulltext/pdf/14-33.pdf.

${ }^{28} \mathrm{See}$ http://dos.elections.myflorida.com/initiatives/initdetail.asp?account=15883\&seq num $=1$.

${ }^{29}$ See http://dos.elections.myflorida.com/initiatives/fulltext/pdf/15883-1.pdf. For a further discussion, see Advisory Op. to Att'y Gen. re Ltd. Casinos, 644 So. 2d 71 (Fla. 1994)

${ }^{30} \mathrm{See}$ http://dos.elections.myflorida.com/initiatives/initdetail.asp?account=16038\&seq num $=1$.

${ }^{31}$ See http://dos.elections.myflorida.com/initiatives/fulltext/pdf/16038-1.pdf. For a further discussion, see Advisory Op. to the Att'y Gen. re Casino Authorization, Taxation and Regulation, 656 So. $2 d 466$ (Fla. 1995).

${ }^{32}$ See http://dos.elections.myflorida.com/initiatives/initdetail.asp?account=16285\&seq num=1

${ }^{33}$ See http://dos.elections.myflorida.com/initiatives/fulltext/pdf/16285-1.pdf.

${ }^{34} \mathrm{See}$ http://dos.elections.myflorida.com/initiatives/initdetail.asp?account=16238\&seq num=1.
} 
more than four in any one county, and used the taxes generated by them "for law enforcement, prisons, economic development, and . . . distribution to local governments. $" 35$ In addition to giving counties and cities the right to opt out, the measure required the vessels to have an "appropriate local theme," be newly constructed, be ecologically friendly, and charge patrons an admission fee and limit their playing time. $^{36}$

Lastly, in 1998, a proposal entitled "Florida Locally Approved Gaming" failed to make the ballot. ${ }^{37}$ It would have permitted the state to authorize a total of 20 casinos, in either hotels or riverboats, with no more than 10 casinos on riverboats. ${ }^{38}$ All counties with at least 500,000 residents were guaranteed a hotel casino license; no riverboat could be located in a county with less than 200,000 residents; and all counties and cities were given the right to opt out. ${ }^{39}$

Having been repeatedly shot down, casino proponents in 2000 decided to try a new tack. As a result, they focused on getting slot machines into existing pari-mutuel facilities. When this effort came up short in $2002,{ }^{40}$ they retooled their proposal so that it applied only to Broward and Miami-Dade counties, historically the state's two most pro-gambling counties. This strategy turned out to be a winning one, as voters approved Amendment 4 in $2004^{41}$
The 2006 election of Charlie Crist as Florida's 44th governor ushered in a more liberal approach to gambling in Tallahassee, and in 2010, the state, after refusing to negotiate with the Seminole Indians for two decades, signed a compact with the tribe allowing it to have Class III games. ${ }^{42}$ Shortly thereafter, the Genting Group purchased 14 acres of prime waterfront real estate in Miami (the former home of the Miami Herald) and began lobbying the legislature for permission to build the world's largest casino ("Resorts World Miami"). When the company explained that it was planning to invest $\$ 3$ billion in the project and expected it to create 100,000 permanent jobs and generate $\$ 250$ million in annual taxes, the Florida Legislature began to listen. ${ }^{43}$ It also commissioned Spectrum Gaming Group to look into the feasibility of turning Florida into a new Las Vegas. In 2013, the firm issued a 708-page report that found the prospect both practical and desirable. ${ }^{44}$

Despite the excitement generated by Genting's proposal and Spectrum's report, the Florida Legislature has been unable to pass a "destination casinos" $" 45$ bill, although it has come close on several occasions and nearly succeeded in $2018 .^{46}$ The possibility of such a bill becoming law greatly concerns Disney and the Seminole Indian tribe, both of which are opposed to any expansion of gambling in Florida. ${ }^{47}$ As a result, they have joined forces
${ }^{35} \mathrm{See}$ http://dos.elections.myflorida.com/initiatives/fulltext/pdf/16238-1.pdf. ${ }^{36} I d$.

${ }^{37} \mathrm{See}$ http://dos.elections.myflorida.com/initiatives/initdetail.asp?account=16295\&seq num=1.

${ }^{38} \mathrm{See}$ http://dos.elections.myflorida.com/initiatives/fulltext/pdf/16295-1.pdf.

${ }^{39} I d$. For a further discussion, see Advisory Op. to the Att'y Gen. re Fla. Locally Approved Gaming, 656 So. 2d 1259 (Fla. 1995).

${ }^{40}$ See supra note 7.

${ }^{41} I d$.

${ }^{42}$ See supra note 9.

${ }^{43}$ See Greg Allen, In Miami, Plans for Mega-Casinos Bring Hope and Ire, NPR (Dec. 1, 2011), https://www.npr.org/2011/12/01/142864058/in-miami-plans-formega-casinos-bring-hope-and-ire.

${ }^{44}$ See Spectrum Gaming Group, Gaming Impact Study: Report for Florida LegISLATURE (Oct. 28, 2013), available at http://www.leg.state.fl.us/GamingStudy/ docs/FGIS_Spectrum_28Oct2013.pdf.

${ }^{45}$ The term "destination casinos" is used by observers to distinguish Florida's existing casinos - which lack craps and roulette, generally do not have hotels, and cater primarily to locals-from the type of casinos proposed by Genting and
Spectrum. These latter casinos, also sometimes called "Las Vegas-style casinos," would be "full-service" and aimed squarely at tourists (primarily from Asia and Latin America)

${ }^{46}$ For a recap of the different bills, see Jim Rosica, Sunshine State Gambling \#Fails: A Short History, FLA. Pol. (Mar. 10, 2018), http://floridapolitics.com/archives/ 258646-sunshine-state-gambling-fails-updated-2018. See also Todd Friedman, Note, Paving the Streets in Gold: A Comparative Analysis of the 2012 Florida Gaming Bill, 66 U. Miami L. Rev. 1183 (2012).

Frustrated by the legislative stalemate, a number of Florida counties, using a supposed loophole in Chapter 551, voted to let their pari-mutuels have slot machines. This "local option" effort came to an end when the Florida Supreme Court held that the loophole did not exist. See Gretna Racing, LLC v. Florida Dep't Bus. \& Prof'l Reg., 225 So. 3d 759 (Fla. 2017).

${ }^{47}$ Disney has long believed that "gambling is inconsistent with Florida's reputation as a family-friendly destination." See Lizette Alvarez and Michael Snyder, In Florida, Gambling Debate Entangles Disney, N.Y. Times, Oct. 27, 2013, at A16 (quoting Disney spokeswoman Andrea M. Finger). The Seminoles, on the other hand, oppose expansion because it would threaten their near monopoly over gambling in Florida (especially in central Florida, where the Seminole Hard Rock Hotel and Casino Tampa is the tribe's biggest moneymaker). See Nick Sortal, Seminoles on Gambling Expansion: Hold. That. Line!, CDC Gaming ReP. (Nov. 21, 2017), https:/www.cdcgamingreports.com/commentaries/seminoles-on-gamblingexpansion-hold-that-line/. 
and now are taking their fight directly to the public via Amendment 3, better known as the "Florida Voters in Charge of Future Gambling Expansion" amendment. ${ }^{48}$

In the pertinent part, Amendment 3 reads as follows:

(a) This amendment ensures that Florida voters shall have the exclusive right to decide whether to authorize casino gambling in the State of Florida. This amendment requires a vote by citizens' initiative pursuant to Article XI, section 3 , in order for casino gambling to be authorized under Florida law. This section amends this Article; and also affects Article XI, by making citizens' initiatives the exclusive method of authorizing casino gambling.

(b) As used in this section, "casino gambling" means any of the types of games typically found in casinos and that are within the definition of Class III gaming in the Federal Indian Gaming Regulatory Act, 25 U.S.C. $\S 2701$ et seq. ("IGRA"), and in 25 C.F.R. $\$ 502.4$, upon adoption of this amendment, and any that are added to such definition of Class III gaming in the future. This includes, but is not limited to, any house banking game, including but not limited to card games such as baccarat, chemin de fer, blackjack (21), and pai gow (if played as house banking games); any player-banked game that simulates a house banking game, such as California black jack; casino games such as roulette, craps, and keno; any slot machines as defined in 15 U.S.C. 1171 (a)(1); and any other game not authorized by Article X, section 15, whether or not defined as a slot machine, in which outcomes are determined by random number generator or are similarly assigned randomly, such as instant or historical racing. As used herein, "casino gambling" includes any electronic gambling devices, simulated gambling devices, video lottery devices, internet sweepstakes devices, and any other form of electronic or electromechanical facsimiles of any game of chance, slot machine, or casino-style game, regardless of how such devices are defined under IGRA. As used herein, "casino gambling" does not include pari-mutuel wagering on horse racing, dog racing, or jai alai exhibitions. For purposes of this section, "gambling" and "gaming" are synonymous. ${ }^{49}$

Since 2006, the Florida Constitution has required proposed amendments to be approved by at least $60 \%$ of the voters. ${ }^{50}$ Even with this high threshold, Amendment 3 stands a good chance of passing. First, early polling has found that voters favor it. ${ }^{51}$ Second, it has no organized opposition. ${ }^{52}$

Obviously, if Amendment 3 becomes law, it will spell the end of the effort to bring destination casinos to Florida. It also will mean that the Florida Legislature will no longer have the ability to shape the state's
${ }^{48}$ According to one source, "As of June 16, 2018, the support campaign, Voters in Charge, had raised $\$ 17.43$ million. The top contributor to the support campaign was Disney Worldwide Services, Inc., which contributed $\$ 9.66$ million. The second largest contributor was the Seminole Tribe of Florida, which contributed $\$ 6.78$ million." Florida Amendment 3, Voter Approval of Casino Gambling Initiative (2018), BalLotPEDIA, https://ballotpedia.org/Florida_Amendment 3, Voter Approval_of_Casino_Gambling_Initiative_(2018) [hereinafter BALLOTPEDIA 3].

${ }^{49}$ For the amendment's complete text, which makes its terms self-executing (see paragraph (d)) and includes a severability clause (see paragraph (e)), see http://dos. elections.myflorida.com/initiatives/fulltext/pdf/64995-1.pdf. The Florida Supreme Court cleared Amendment 3 for inclusion on the ballot in Advisory Op. to the Att'y Gen. re Voter Control of Gambling in Fla., 215 So. 3d 1209 (Fla. 2017). Justices Lewis and Polston dissented from the per curiam decision, concerned that Amendment 3's wording might call into question the right of Broward and MiamiDade's pari-mutuels to continue to have slot machines:

Here, the ballot title and summary do not clearly inform the public that the proposed amendment may substantially affect slot machines approved by county-wide referenda pursuant to article X, section 23, Florida Constitution, or pursuant to validly enacted statutes. Although the ballot summary references article $\mathrm{X}$ of the Florida Constitution, there is no explanation whatsoever of how the proposal affects the slot machines constitutional provision found there. . . As a result, the public cannot fully comprehend how the initiative will affect article $\mathrm{X}$, and the initiative's effect is left unresolved and open to multiple interpretations. ...
The initiative is placing voters in the position of deciding between a preference for controlling the expansion of full-fledged casino gambling and Florida's current legal gaming landscape. . . . And it is doing so without clearly informing the voters that this is the choice they are making. . $I d$. at $1218-19$. The majority responded by writing: "[W]e do not address whether the amendment would apply retroactively if the Initiative is placed on the ballot and passed by voters, including whether the Initiative would retroactively affect licenses previously issued pursuant to article $\mathrm{X}$, section 23, of the Florida Constitution and section 551.102, Florida Statutes (2016).” Id. at 1217 .

${ }^{50}$ See FLA. Const. art. XI, $\S 5$ (e). Prior to 2006, a simple majority was sufficient. See D'Alemberte, supra note 3, at 325.

${ }^{51}$ See, e.g., Lloyd Dunkelberger, Four of 13 Amendments on Ballot Have Voter Support, Poll Shows, S. Fla. Sun-Sentinel, June 18, 2018, at 1B (Florida Chamber of Commerce poll); Jim Rosica, Poll: 76 Percent Support Constitutional Amendment on Gambling, FLA. Pol. (Feb. 8, 2018), http://floridapolitics.com/ archives/255744-76-percent-support-amendment (Voters in Charge poll).

${ }^{52}$ See Nick Sortal, Opposition Lacking to Florida Gambling Amendment, CDC GAming ReP. (Feb. 20, 2018), https://www.cdcgamingreports.com/commentaries opposition-lacking-to-florida-gambling-amendment/. See also BallotPedia 3, supra note 48 
overall gambling policy. Instead, every proposed change will have to go through the cumbersome citizen petition process. ${ }^{53}$ As others have noted, this will put Florida's gambling operators in an unenviable position:

"It's game over for the Legislature if that (constitutional) amendment ... passes. And at that point, we'll just be spectators in the world of gaming, which will essentially be a monopoly for the Seminole Tribe," Sen. Bill Galvano, a Bradenton Republican who has been instrumental in gambling-related legislation for eight years, told the News Service on Wednesday.

Industry representatives also foreshadowed dire consequences if the constitutional amendment passes.

"I think it will have a huge impact on our industry, because as opposed to the Legislature regulating us, we'll need 60 percent of the residents of Florida to regulate us in the future. And, as the most regulated business in the state, that just makes anything we want to do to grow our business in the future more difficult," Izzy Havenick, whose family owns dog tracks in Naples and Miami, said in an interview. . . .

Nick Iarossi, a lobbyist who represents numerous gambling operators, said the proposal would have a chilling effect on the industry.

"The fear that they all have is that, if this No Casinos amendment passes in November, we will never have that opportunity without a statewide approval to add new product, whether it be slots or otherwise. And to try to get that approval statewide when you have Disney and the Seminole Tribe with their monopoly putting money in against any type of expansion you place on the ballot, it's going to be impossible to get those votes with the 60 percent threshold," he said. ${ }^{54}$

Lastly, it is possible that Amendment 3 could be construed by the courts to apply to sports betting. ${ }^{55}$ If this were to occur, it would make the legalization of such betting in Florida nearly impossible, because such betting then would require a statewide referendum and a $60 \%$ positive vote. $^{56}$

\section{PROPOSED AMENDMENT 13}

Every 20 years, the Florida Constitution requires the appointment of a Constitution Revision Commission (CRC) ${ }^{57}$ The job of the CRC is to "examine the constitution of the state, hold public hearings, and, not later than one hundred eighty days prior to the next general election, file with the custodian of state records its proposal, if any, of a revision of this constitution or any part of it." ${ }^{58}$ Having last convened in 1997-98, ${ }^{59}$ a new CRC began meeting on March 20, 2017..$^{60}$ On October 31, 2017 (the last day to do so), CRC Commissioner Tom Lee ${ }^{61}$ asked for a ban on dog racing. ${ }^{62}$

As finally adopted by the CRC on April 16, 2018, Lee's suggestion - originally Proposal 67, later re-

\footnotetext{
${ }^{53}$ See supra note 16. See also Carole Fernandez, League Backs Four of 13 Amendments on Ballot, GAINesville Sun, June 29, 2018, available at http://www. gainesville.com/opinion/20180629/carole-fernandez-league-backs-four-of-13amendments-on-ballot ("Amendment 3 would strip away the Florida Legislature's authority to pass a law approving new casino gambling in Florida. Any new casino gambling would require voter approval of a constitutional amendment proposed only through a citizen initiative.")

${ }^{54}$ Dara Kam, Anti-Gambling Measure to Go on November Ballot, WUSF NEWs (Jan. 17, 2018), http://wusfnews.wusf.usf.edu/post/anti-gambling-measure-gonovember-ballot.

${ }^{55}$ As explained supra note 12, in May 2018 the U.S. Supreme Court returned responsibility for sports betting to the states.

${ }^{56}$ Amendment 3 does not specifically mention sports betting. Nevertheless, its supporters believe it reaches such gambling. See Brian Bandell, Supreme Court Ruling on Sports Gambling Could Raise Stakes for Amendment Vote in Florida, S Fla. Bus. J., May 29, 2018, at https://www.bizjournals.com/southflorida/news/ 2018/05/29/supreme-court-ruling-on-sports-gambling-could.html ("The question is whether passage of Amendment Three would mean sports gambling would only be legal in Florida if a statewide referendum allows it, essentially taking the issue out of the hands of the Legislature. John Sowinski, who heads the Yes on Three campaign for No Casinos, said the amendment would apply to sports betting, meaning it could not be introduced in Florida without another statewide referen-
}

dum. He believes the definition of federal Class III gambling, as cited in Amendment Three, applies to sports betting.")

${ }^{57}$ See FLA. ConST. art. XI, § 2(a). The Constitution Revision Commission (CRC) consists of 37 members: the attorney general; 15 persons chosen by the governor; nine persons chosen by the president of the Florida Senate; nine persons chosen by the speaker of the Florida House Representatives; and three persons chosen by the chief justice of the Florida Supreme Court. Id.

${ }^{58} I d$. at $\S 2(\mathrm{c})$.

${ }^{59}$ See W. Dexter Douglass, The 1997-98 Constitution Revision Commission: Valuable Lessons from a Successful Commission, 52 FLA. L. REv. 275 (2000).

${ }^{60}$ See Constitution Revision Commission 2017-2018, at https://www.flcrc.gov/ about/history.

${ }^{61}$ For a biography of Lee, a Tampa homebuilder and a member of the Florida Senate, see https://www.flcrc.gov/Commissioners/Lee (explaining that Lee was appointed to the CRC by Florida House Speaker Richard Corcoran).

${ }^{62}$ See Bill Cotterell, Florida Senator Wants to Ban Greyhound Racing, News-Press (Fort Myers, FL), Nov. 4, 2017, at A24. See also Let Voters Be Heard on Deadly Dog Races, S. Fla. Sun-Sentinel, Nov. 25, 2017, at 15A ("It's time to ban dog racing in Florida. . . . State Sen. Tom Lee . . . is offering the public an opportunity to make that decision in next year's general election. His effort deserves your support."). 
designated Proposal 6012, still later called Revision 8 , and now on the ballot as Amendment $13^{63}$ _reads as follows:

The humane treatment of animals is a fundamental value of the people of the State of Florida. After December 31, 2020, a person authorized to conduct gaming or pari-mutuel operations may not race greyhounds or any member of the Canis Familiaris subspecies in connection with any wager for money or any other thing of value in this state, and persons in this state may not wager money or any other thing of value on the outcome of a live dog race occurring in this state. The failure to conduct greyhound racing or wagering on greyhound racing after December 31, 2018, does not constitute grounds to revoke or deny renewal of other related gaming licenses held by a person who is a licensed greyhound permitholder on January 1, 2018, and does not affect the eligibility of such permitholder, or such permitholder's facility, to conduct other pari-mutuel activities authorized by general law. By general law, the legislature shall specify civil or criminal penalties for violations of this section and for activities that aid or abet violations of this section. ${ }^{64}$

Dog racing in Florida began in $1922 ;{ }^{65}$ by 1927 , dog tracks were operating in Miami, Miami Beach, Orlando, and St. Petersburg. ${ }^{66}$ In 1931, Florida became the first state to allow pari-mutuel betting on dog races. ${ }^{67}$
At its peak in 1989, dog racing was sanctioned by 19 states. ${ }^{68}$ Today, however, dog races are held in just six states: Alabama, Arkansas, Florida, Iowa, Texas, and West Virginia. ${ }^{69}$ Collectively, these jurisdictions have 18 dog tracks, although the bulk (12) are located in Florida. ${ }^{70}$

As the sport's popularity has declined, so has its contributions to Florida's treasury:

In fiscal year 1988, the total handle - the aggregate amount of bets taken-for dog racing in Florida was $\$ 1.02$ billion, according to the state's yearly report. It brought in $\$ 80.59$ million in taxes for the state.

By contrast, in fiscal year 2016 - the last for which numbers are available - wagering on greyhound races amounted to $\$ 239.92$ million. The state got $\$ 2.85$ million in taxes and fees. ${ }^{71}$

In addition to no longer being lucrative, ${ }^{72}$ dog racing has come under increasing attack by animal rights activists:

[Florida] Attorney General Pam Bondi, who has made dog-adoption efforts part of the opening of each state Cabinet meeting, called greyhound racing and the treatment of the dogs a "black eye on our state."

"We all know these dogs end up with broken legs, serious injuries and they're shipped from track to track until they're dead or can no longer
${ }^{63}$ For the various iterations, see:

https://flcrc.gov/Proposals/Commissioner/2017/0067 (Proposal 67); https://flcrc.gov/Proposals/Commissioner/2017/6012 (Proposal 6012); http://dos.elections.myflorida.com/initiatives/fulltext/pdf/11-27.pdf (Revision 8); and,

http://dos.elections.myflorida.com/initiatives/initdetail.asp?account= 11\&seqnum=27 (Amendment 13).

See also Florida Ban on Wagering on Dog Races Amendment (2018), BaLlotPediA, https://ballotpedia.org/Florida_Ban_on_Wagering_on_Dog_Races_Amendment_ (2018).

${ }^{64} \mathrm{See}$ http://dos.elections.myflorida.com/initiatives/fulltext/pdf/11-27.pdf.

${ }^{65}$ See Donald D. Spencer, History of Gambling in Florida 118 (2007).

${ }^{66}$ See The Most Exciting Dogs in the World, Greyhound Racing Ass'N of Am., http://www.gra-america.org/the_sport/history.html.

${ }^{67}$ See SPENCER, supra note 65, at 122.

${ }^{68}$ See History of Dog Racing in the United States, GREY2K USA WorLdWIDE, https://www.grey2kusa.org/pdf/GREY2K_USA_History-of-Dog-Racing-in-the-

United-States.pdf (listing Alabama, Arizona, Arkansas, Colorado, Connecticut,
Florida, Idaho, Iowa, Kansas, Massachusetts, Nevada, New Hampshire, Oregon, Rhode Island, South Dakota, Texas, Vermont, West Virginia, and Wisconsin as states allowing dog racing).

${ }^{69}$ See Greyhound Racing in the United States, GrEY2K USA WorLdwide, https:// www.grey2kusa.org/about/states.php. In four other states (Connecticut, Kansas, Oregon, and Wisconsin), dog racing is legal but there are no active tracks. Id. Dog racing is illegal in the rest of the United States. Id.

${ }^{70} I d$. Florida's tracks are sprinkled throughout the state, with five in central Florida (Daytona Beach, Longwood, Melbourne, Sarasota, and St. Petersburg); three in southeast Florida (Hallandale Beach, Miami, and West Palm Beach); two in northwest Florida (Ebro and Pensacola); and one each in northeast Florida (Jacksonville) and southwest Florida (Bonita Springs). See Tracks, FloridA GREYHOUND Ass'N, http://www.floridagreyhoundassociation.com/tracks.

${ }^{71}$ Arin Greenwood, Racing for Profits, 104 ABA J. 18, 19 (Jan. 2018).

${ }^{72}$ In fact, Florida actually now loses money on dog racing, as it spends $\$ 1.8$ million more regulating the sport than it collects in gambling taxes. See Sheila MacVicar and David Martin, Why Do Florida Track Owners Want to Stop Greyhound Racing?, Aljazeera Am. (Jan. 12, 2015), http://america.aljazeera.com/watch/shows/ america-tonight/articles/2015/1/12/florida-greyhounds.html. 
race at all," said Bondi, who is a member of the Constitution Revision Commission. . . . [CRC] Commissioner Don Gaetz . . . said . . . that state lawmakers have been unable to act on various issues about greyhound racing.

"We've tried to get bills passed on injury reporting. We've tried to get bills passed on doping," said Gaetz, a former state Senate president from Niceville. "And every time we have, there are fine and good people in this industry, but the mass of the industry has come forward with their lobbyists to do everything they could to stop them from reforming themselves and [to] stop the reasonable regulation of the industry." 73

While many Floridians back Amendment $13,{ }^{74}$ on May 17, 2018, the Florida Greyhound Association $(\mathrm{FGA})^{75}$ filed a lawsuit in Leon County (Tallahassee) circuit court to have it struck from the ballot:

Among the shortcomings alleged by the plaintiffs: The proposal does not advise voters that dog tracks still would be allowed to broadcast live greyhound races from other states. And the measure would only ban "commercial" dog racing, which means that kennel clubs would be allowed to continue dog competitions, the complaint says.
The lawsuit also alleges that the text of the proposal - which voters won't see on the ballot [due to space limitations] - could have implications far beyond the greyhound-racing industry.

The proposed amendment says the "humane treatment of animals is a fundamental value of the people of the State of Florida."

That language "might ultimately apply to animals other than dogs," plaintiffs' lawyers Jeff Kottkamp, a former lieutenant governor, and Paul Hawkes, a former appellate judge, wrote in the 17-page complaint. ${ }^{76}$

Although Judge Karen A. Gievers initially scheduled a bench trial for July 26, 2018, ${ }^{77}$ on June 29,2018 she cancelled it and announced plans to rule on the parties' papers. ${ }^{78}$ Regardless of what she decides, almost everyone believes the case will end up at the Florida Supreme Court. ${ }^{79}$

In the meantime, a tough fall campaign already is taking shape. ${ }^{80}$ Two competing citizens groups have been established, ${ }^{81}$ with the "Yes on 13" group calling itself the "Committee to Protect Dogs" 82 and the "No on 13" group using the name "Committee to Support Greyhounds. ${ }^{, 83}$ In previewing the expected battle, one observer has written:
${ }^{73} \mathrm{Jim}$ Turner, Greyhound Racing Ban Approved for Ballot, FLA. TIMES-UNION (Jacksonville), Apr. 18, 2018, at B1.

In 2017, the public was shocked to learn that dozens of Florida greyhounds had been injected with cocaine to make them run faster:

And now, cocaine. At least 22 greyhound racing dogs have tested positive for cocaine in Florida so far this year, adding yet another ghastly taint to an infamously abusive pari-mutuel.

In May, the state yanked the license of a veteran trainer at Derby Park in St. Petersburg after urine tests found traces of cocaine metabolites in five of his dogs, according to the Tampa Bay Times.

Then another 17 dogs tested positive for coke at the Orange Park Kennel Club near Jacksonville. Actually, state regulators reported that those $17 \mathrm{dogs}$ rang up 23 cocaine-positive results among them, according to First Coast News.

We can add this latest doping outrage to the 2014 scandal involving a South Florida trainer caught injecting anabolic steroids into his greyhounds.

Fred Grimm, Doped Up Greyhounds Add to the Disgrace Dogging Parimutuels in Florida, Miami Herald, July 23, 2017, at 9B.

For a further look at these matters, see, e.g., Gwyneth ANNE THAYeR, Going to the Dogs: Greyhound Racing, Animal Activism, and American Popular Culture (2013); Victoria Lynn Perniola, Greyhound Racing: Florida's Most Dependent Child, 7 J. Animal \& Envtl. L. 63 (2015); Addie Patricia Asay, Comment, Greyhounds: Racing to Their Deaths, 32 Stetson L. Rev. 433 (2003).

${ }^{74}$ See Marc Caputo, Poll: Florida Voters Favor Greyhound Racing Ban, Poutico (Mar. 20, 2018), https://www.politico.com/states/florida/story/2018/03/20/pollflorida-voters-favor-greyhound-racing-ban-321104 (Grey2K USA Worldwide poll finding $65 \%-27 \%$ support); Dunkelberger, supra note 51 (Florida Chamber of Commerce poll finding $47 \%-36 \%$ support).
${ }^{75}$ For more information about the Florida Greyhound Association (FGA), see http://www.floridagreyhoundassociation.com/.

${ }^{76}$ Dara Kam, Association Sues to Get Dog Racing Ban Off Ballot, S. Fla. SunSentinel, May 27, 2018, at 1B [hereinafter Association Sues]. For a copy of the complaint, which is entitled Florida Greyhound Association, Inc. v. Department of State, 372018 CA 001114 (Fla. Cir. Ct. Leon Cnty., filed May 17, 2018), see http:// miamiherald.typepad.com/files/fga-v-secretary-of-state-complaint.docx.

${ }^{77}$ See Jim Rosica, Lawsuit Over Dog-Racing Ban Heads to Court, Fla. Pol. (June 29, 2018), http://floridapolitics.com/archives/267656-judge-denies-motion-dogracing.

${ }^{78}$ See Jack Stofan, Trial Canceled for Greyhound Amendment Suit, News4JAX.cOM (July 6, 2018), https://www.news4jax.com/news/florida/trial-canceled-for-grey hound-amendment-suit.

${ }^{79} I d$.

${ }^{80}$ See, e.g., Brent Batten, Dog Fight Begins over Racing Ban, NAPLES DAILY News, June 7, 2018, at A7 (predicting that by the time "the campaign ends, millions are likely to have been raised and spent")

${ }^{81}$ See Committee to Oppose Greyhound-Racing Ban Announces Formation, Fla. Pol. (June 4, 2018), http://floridapolitics.com/archives/265316-committeegreyhounds-formation.

${ }^{82}$ See https://protectdogs.org/.

${ }^{83} \mathrm{See}$ http://www.supportgreyhounds.org/. Support Greyhounds "is led by Jennifer Newcome, a retired dog trainer who left Massachusetts for Florida after a similar ballot initiative ended greyhound racing there in 2010." See Batten, supra note 80. 
Opponents [to dog racing] have an internet advertisement that goes right for the heart.

"Every three days, a greyhound like this one dies on a racetrack in Florida," says a voice in the ad, over scenes showing dogs stumbling on a track. "Death comes from cardiac arrest, broken necks, broken legs and other injuries. Nearly 500 greyhound dogs have died in Florida since 2013." This pitch is spliced with quick-cut shots of beautiful, friendly dogs curiously nosing the camera lens - when not confined to small steelmesh cubicles. The web site protectdogs.org lists scores of facts and figures about the greyhound industry - which may or may not be accuratebut the totality of the message is aimed at the emotions, not the mind.

The Committee to Protect Dogs, which sponsored the internet site, reported campaign contributions of $\$ 55,575$ so far, all of it from an "animal advocacy group" called Grey2K USA in Arlington, Va. The political group is aligned with the Humane Society of the United States.

If it doesn't succeed in scratching Amendment 13 in court, the racing industry still has some political advantages. It only needs 40 percent (plus one) to defeat the proposal at the polls, which means the proponents need one and a half "yes" votes for every "no" the opponents can muster. There will probably be some people who will just vote against all the constitutional amendments.

But being at the back of the pack can also work the other way. "Voter fatigue" - the drop-off of interest when the ballot is long and not exactly fascinating - could lower the total turnout on Amendment 13. That gives both sides a smaller number to shoot for. ${ }^{84}$

Because of the way it is written, Amendment 13 does not close Florida's dog tracks. Instead, it "decouples" them. In other words, while they will no longer be allowed to hold races, they still will be allowed to have card rooms (and, in Broward and Miami-Dade counties, slot machines). ${ }^{85}$ This has been the long-time goal of most of Florida's pari-mutuel facilities, whose profits would soar if they could rid themselves of their dogs, horses, and jai-alai players. ${ }^{86}$

Thus, if Amendment 13 wins, the Florida Legislature is likely to be heavily lobbied by both horse tracks and jaialai frontons for laws decoupling their facilities. ${ }^{87}$ The Florida Legislature also is likely to be lobbied by dog breeders, dog track workers, and anyone else who loses their job due to Amendment 13. According to Jack Cory, the FGA's chief lobbyist, Amendment 13 will "cost 3,000 direct jobs [and] 10,000 indirect jobs[.]" 88

A successful Amendment 13 campaign also may prompt horse tracks and jai-alai frontons to sponsor
${ }^{84}$ Bill Cotterell, Campaign to Ban Dog Racing Aims for the Heart, TAlLAHASSEE DемосRAт, June 16, 2018, available at https://www.tallahassee.com/story/news politics/cotterell/2018/06/16/cotterell-campaign-ban-dog-racing-aims-heart/ 36100097/.

${ }^{85}$ At present, running races or holding jai-alai matches is the only way for a parimutuel facility to keep its other gambling licenses:

The motivation for continuing greyhound racing in Florida is no secret. Pursuant to Florida law, only a "pari-mutuel permitholder" is permitted to operate a card room. A "pari-mutuel facility" is defined by statute as "a racetrack, fronton, or other facility used by a permitholder for the conduct of pari-mutuel wagering." Pari-mutuel facilities are allowed to offer wagering on jai alai, horse racing, or greyhound racing. To operate a cardroom in Florida, you must also be a licensed pari-mutuel permitholder. Licensed cardrooms can offer poker and/or dominoes. In addition to card games, slot machine gaming is authorized at pari-mutuel facilities in Miami-Dade County and Broward County.

As a result of this legislation, greyhound racing and cardrooms are essentially joined at the hip. With the exception of Indian gaming facilities, only a parimutuel facility can operate a card room in Florida. Therefore, if a facility wishes to continue to offer profitable card games, it must also continue to race greyhounds and maintain a full schedule of live racing, which consists of no fewer than $90 \%$ of the live races the facility conducted during the fiscal year that its card room license was issued or the fiscal year before it was issued.

Ryan Parker, The Proposed Constitutional Amendment to Ban Greyhound Racing in Florida, Paw Rev. (Fla. B. Animal L. Sec. Newsl.) 4, 4 (Winter 2018), text available at https://www.floridabar.org/dasset/cmdocs/bs100.nsf/c5aca7f8c251a58d85257
236004a107f/14ca552ef7a35bd685258226006a7ca0/\%24FILE/P67\%20White\% 20Paper.pdf.

${ }^{86}$ See further Nick Sortal, Jai-alai Has Gained Bounce, Thanks to Pari-Mutuel Expansion, CDC GAMING Rep. (Feb. 6, 2018), https://www.cdcgamingreports.com/ commentaries/jai-alai-has-gained-bounce-thanks-to-pari-mutuel-expansion/ (explaining that jai-alai still exists in Florida only because of coupling); Bill White, Florida Could "Decouple" Horse Racing, Breeding Right Out of Business, FHBPA BLOG (Sept. 22, 2015), http://floridahbpa.com/florida-could-decouple-horseracing-breeding-right-out-of-business/ ("But to Big Casinos vying to rid themselves of Florida horse racing's tie to slot machines, live racing days are nothing but an inconvenient dent in their corporate bottom line."); MacVicar and Martin, supra note 72 (noting that at the Naples-Fort Myers Greyhound Track and Poker Room, dog racing reduces the facility's total yearly profits by $\$ 2.5$ million).

${ }^{87}$ Such laws would not run afoul of Amendment 3 , which specifically says that it does not apply to pari-mutuel facilities. See supra text accompanying note 49 .

${ }^{88}$ Troy Kinsey, Florida's Greyhound Tracks Set to Sue Over Ballot Amendment, TAMPA Bay News 9 (Apr. 18, 2018), http://www.baynews9.com/fl/tampa/news/ 2018/04/18/greyhound-racing-lawsuit. Cory also believes that Amendment 13 will lead to numerous greyhound deaths because "there is no way to absorb eight thousand animals over the next two years into the adoption program." Id. Both the U.S. Supreme Court and the Florida Supreme Court have held that no compensation is due when a business is closed by the government to protect the public. See Hamilton v. Kentucky Distilleries \& Warehouse Co., 251 U.S. 146 (1919) (alcohol); Pompano Horse Club v. State, 111 So. 801 (Fla. 1927) (gambling). Nevertheless, the Florida legislature could pass a private claims bill (see FLA. Stat. § 768.28(5)) to help soften Amendment 13's economic blow. Amendment 13 itself is silent on the issue of job-loss compensation. 
their own constitutional amendments. It thus does not seem farfetched to believe that if dog racing is outlawed, horse racing and jai-alai likewise could disappear from Florida.

\section{v. CONCLUSION}

Despite officially being opposed to gambling, ${ }^{89}$ Florida historically has been a leader in the field ${ }^{90}$ and today relies heavily on wagers to fund its state budget. ${ }^{91}$ Yet after years of steadily increasing its bets, ${ }^{92}$ 2018 might just be the moment that Florida decides to take a step back.

\section{POSTSCRIPT}

After this article was sent out for typesetting, two significant developments occurred. First, the pari-mutuel industry belatedly organized a political committee to oppose Amendment 3. ${ }^{93}$ Second, on August 1, 2018, Judge Gievers ruled that Amendment 13 was invalid and struck it from the ballot. ${ }^{94}$ Within 48 hours, the State of Florida had appealed the decision to the First District Court of Appeal in Tallahassee and both sides had requested an immediate transfer to the Florida Supreme Court (as permitted by Article $\mathrm{V}, \S 3(\mathrm{~b})(5)$ of the Florida Constitution).$^{95}$

\begin{abstract}
${ }^{89}$ As explained supra text accompanying note 14, Florida law makes all forms of gambling illegal unless specifically authorized.

${ }^{90}$ In 1979, for example, the Seminoles opened a high-stakes bingo hall on their reservation west of Fort Lauderdale. This development now is recognized as the start of the country's \$28 billion-a-year Indian gambling industry. See Tonya Kowalski and Robert M. Jarvis, Indian Courts, in FloridA's Other CourTs: UN conventional Justice in the Sunshine State 172-73 (Robert M. Jarvis ed. 2018). See also supra notes 11 (Florida first state to have modern casino boats) and 67 (Florida first state to authorize pari-mutuel betting on dog races).

${ }^{91}$ See Steven Peters and Thomas C. Frohlich, States Spending the Most (and Least) on Gambling, 24/7 WALL ST. (Mar. 11, 2017), https://247wallst.com/special-report/ 2017/03/11/states-spending-the-most-and-least-on-gambling/ (reporting that gambling funds $5.2 \%$ of Florida's state budget). Florida's gambling tax receipts amount to $\$ 1.69$ billion a year, with most of the money ( $88 \%$ ) supplied by the lottery. See Lucy Dadayan, State Revenues from Gambling: Short-Term Relief, Long-Term DisapPoIntMent 26 (Apr. 2016), available at http://rockinst.org/wpcontent/uploads/2017/11/2016-04-12-Blinken_Report_Three-min.pdf.

${ }^{92}$ Between 2004 and 2017, for example, Florida witnessed (among other things): a doubling of its lottery sales, see supra note 6; the legalization of slot machines in Broward and Miami-Dade counties, see supra note 7; and the signing of its first Indian gambling compact, see supra note 9.

${ }^{93}$ See Jim Rosica, New Committee Forms to Fight Gambling-Control Amendment, FLA. PoL., July 13, 2018, at http://floridapolitics.com/archives/268717-politicalcommittee-gambling-measure (explaining that the "committee . . . is chaired by South Florida's Isadore 'Izzy' Havenick, whose family operates Magic City Casino in Miami and Naples-Fort Myers Greyhound Racing \& Poker in Bonita Springs.”).

${ }^{94}$ In summarizing Judge Gievers' opinion, one reporter wrote:
\end{abstract}

Saying it "hide(s) the ball" and calling it "outright "trickeration,"” a Tallahassee judge has ruled that a proposed constitutional amendment aimed at ending dog racing shouldn't go on the November ballot. . . .
Among other things, Circuit Judge Karen Gievers' 27-page order . . . said Amendment 13's ballot title and summary would mislead voters into believing a 'yes' vote was an outright ban on greyhound racing.

The amendment bans betting on live dog racing in Florida, and doesn't make clear that trackgoers in Florida could still bet on 'simulcast' dog races outside Florida, she said. . .

It also doesn't make clear, Gievers added, that a vote for the amendment is a vote for other gambling - such as card games and slot machines - to continue at tracks that have them.

Gievers said the amendment title and summary were "clearly and conclusively defective," a legal standard developed by the Supreme Court to justify keeping proposed amendments off the ballot.

Specifically, a ballot summary is defective if it "fails to specify exactly what was being changed, thereby confusing voters" or "gives the appearance of creating new rights or protections, when the actual effect is to reduce or eliminate rights or protections already in existence," the court has said. Amendment 13 doesn't provide voters with the "'truth in packaging' to which they are entitled," she wrote. . .

[Gievers also] said the ballot title and summary don't disclose that "humane treatment of animals would become a fundamental value of the people of Florida[.]"

Jim Rosica, Judge Strikes Down Dog-Racing Ban, Calling It 'Outright Trickeration, 'Fla. Pol., Aug. 1, 2018, at http://floridapolitics.com/archives/270510-judgestrikes-down-dog-racing-ban-calling-it-outright-trickeration. For a copy of Judge Gievers's opinion, see https://cloudup.com/c4zwVNc70uD.

${ }^{95}$ See Department of State v. Florida Greyhound Ass'n, Case No. 1D18-3260 (Fla. 1st Dist. Ct. App.) (Notice of Appeal and Joint Suggestion for Pass-Through Certification and Joint Request for Expedited Treatment filed Aug. 3, 2018), at http://onlinedocketsdca.flcourts.org/DCAResults/LTCases?

CaseNumber $=3260 \&$ CaseYear $=2018 \&$ Court $=1$. 